\title{
PERONEUS LONGUS ACTIVITY IN DIFFERENT TYPES OF TAPING: ATHLETES WITH ANKLE INSTABILITY
}

\author{
ATIVIDADE DO MÚSCULO FIBULAR LONGO COM DIFERENTES TIPOS DE BANDAGEM FUNCIONAL \\ EM ATLETAS COM INSTABILIDADE NO TORNOZELO
}

Artigo Original

OrIGINAL ARTICLE

Artículo Original

Muhammad Rahmani Jaffar? (Sports \& Exercise Physician)

Zulkarnain Jaafar ${ }^{2}$

(Sports \& Exercise Physician)

Goh Siew Li ${ }^{3}$

(Sports \& Exercise Physician)

1. University of Malaya, Department of Sports Medicine, Kuala Lumpur, Malaysia.

2. National Sports Institute of Malaysia, Biomechanic Lab (Venue of subjects, tests \& data collection). 3. Sports CentreBiomechanic Lab, University of Malaya (Venue of data analysis, biomechanic consultation).

\section{Correspondence:}

University of Malaya

Department of Sports Medicine,

JalanUniversiti, 50603, Kuala Lumpur, Wilayah Persekutuan Kuala Lumpur, Malásia. (rahmani@ummc.edu.my)

\begin{abstract}
Introduction: Participation in sport among university athletes in Malaysia has progressed right up to Olympic level. However, some of these athletes are prevented from competing due to injuries. Ankle injuries, in particular, are among the common types of injury. Even so, there is still lack of local data and research describing the incidence of ankle injuries. Objectives: To determine peroneus longus muscle activity in different taped ankles and positions among subjects with functional ankle instability (FAl). Methods: Twenty-three subjects with ankle instability (AJFAT score > 26) volunteered to take part in the study. The subjects were tested under three conditions; 1) no tape (NT), 2) Kinesio ${ }^{\oplus}$ tape (KT), and 3) rigid tape (RT). The subjects completed two postural stability tests, followed by a sudden inversion perturbation test with EMG, recording throughout the procedures. The EMG data were analyzed, filtered, full-wave rectified and normalized. The data were analyzed by analysis of variance (Independent T-test and ANOVA) to evaluate differences in peak muscle activation ( $\mathrm{mV}$ ) and peroneal latency (ms). Results: Peak muscle activation of the peroneus was activated more in the RT group during both the Static and Dynamic Stability Tests. Apart from that, there were no statistically significant differences. During sudden inversion perturbation, the RT group was the one that was most activated $(p=0.001)$. Peroneal latency was even delayed in KT and RT during the three tests, and shorter in the NT group. There were significant differences during the Dynamic Stability Test, between the NT and KT groups $(p=0.001)$ and between the NT, RT and KT groups ( $p=0.001)$. Conclusion: RT tape may enhance the peroneus longus response by maintaining a higher level of muscle activation, especially during dynamic movements and sudden inversion of the ankle, and may selectively benefit individuals with FAI. The KT ankle did not show superior effect to the NT ankle, and demonstrated minimal benefit when used in FAl. Also, its use may be more likely to cause reinjury to the ankle.
\end{abstract}

Keywords: athletes; ankle; ankle joint; ligaments, articular.

\section{RESUMO}

Introdução: A participação nos esportes entre atletas universitários na Malásia progrediu atéo nivel olímpico. Contudo, alguns desses atletas são impedidos de competir em decorrência de lesões. As lesões no tornozelo estão entre os tipos mais comuns. Além disso, há falta de dados locais e pesquisas que descrevam a incidência dessas lesões. Objetivos: Determinar a atividade do músculo fibular longo com diferentes bandagens funcionais e posições do tornozelo entre indivíduos com instabilidade funcional do tornozelo (IFT). Métodos: Vinte e três indivíduos com instabilidade no tornozelo (escore AJFAT > 26) foram voluntários no estudo. Os individuos foram testados em três situações: 1) sem bandagem (SB), 2) bandagem Kinesio ${ }^{\oplus}(B K)$, e3) bandagem rígida (BR). Os indivíduos concluiram dois testes de estabilidade postural, seguidos por um teste de perturbação por inversão repentina com EMG, que registrou os procedimentos do começo ao fim. Os dados EMG foram analisados, filtrados, retificados por onda completa e normalizados. Os dados foram analisados por análise de variância (teste Tindependente e ANOVA) para avaliar as diferenças de ativação muscular máxima (mV) e latência fibular (ms). Resultados: A ativação muscular máxima da fibula ocorreu mais no grupo BR durante os testes de estabilidade estática e dinâmica. Além disso, não houve diferenças estatisticamente significantes. Durante a perturbação por inversão, o grupo $B R$ foi o que teve maior ativação $(p=0,001)$. A latência fibular foi mais tardia nos grupos $B K$ e $B R$ durante os três testes $e$ foi menor no grupo SB. Não houve diferenças significantes durante o teste de estabilidade dinâmica entre os grupos SB $e$ $B K(p=0,001)$ e entre os grupos $S B, B R$ e $B K(p=0,001)$. Conclusão: $A B R$ pode ampliar a resposta do músculo fibular longo, porque mantém um nível maior de ativação muscular, especialmente durante os movimentos dinâmicos e a inversão súbita do tornozelo, podendo beneficiar seletivamente os indivíduos com IFT. A BK não apresentou efeito superior com relação à SB, e demonstrou benefício mínimo quando usada para IFT. Ainda, é provável que seu uso cause nova lesão no tornozelo.

Descritores: atletas; tornozelo; articulação do tornozelo; ligamentos articulares.

\section{RESUMEN:}

Introducción: La participación en los deportes entre atletas universitarios en Malasia progresó hasta el nivel olímpico. Sin embargo, algunos de esos atletas son impedidos de competir a raíz de lesiones. Las lesiones en el tobillo están entre los tipos más comunes. Además, hay falta de datos locales e investigaciones que describan la incidencia 
de esas lesiones. Objetivos: Determinar la actividad del músculo fibular largo con diferentes vendajes funcionales y posiciones del tobillo entre individuos con inestabilidad funcional del tobillo (IFT). Métodos: Veintitrés individuos con inestabilidad en el tobillo (score AJFAT > 26) fueron voluntarios en el estudio. Fueron realizados tests con los individuos en tres situaciones: 1) sin vendaje (SV), 2) vendaje Kinesio ${ }^{\oplus}(V K)$, y 3) vendaje rígido (VR). Los individuos concluyeron dos tests de estabilidad postural, seguidos por un test de perturbación por inversión repentina con EMG, que registró los procedimientos desde el inicio al fin. Los datos EMG fueron analizados, filtrados, rectificados por onda completa y normalizados. Los datos fueron analizados por análisis de variancia (test T independiente y ANOVA) para evaluar las diferencias de activación muscular máxima (mV) y latencia fibular (ms). Resultados: La activación muscular máxima de la fibula ocurrió más en el grupo VR durante los tests de estabilidad estática y dinámica. Además, no hubo diferencias estadísticamente significativas. Durante la perturbación por inversión, el grupo VR fue el que tuvo mayor activación $(p=0,001)$. La latencia fibular fue más tardía en los grupos VK y VR durante los tres tests y fue menor en el grupo SV. No hubo diferencias significativas durante el test de estabilidad dinámica entre los grupos SV y VK ( $p=$ $0,001)$ y entre los grupos SV, VR y VK ( $p=0,001)$. Conclusión: La VR puede ampliar la respuesta del músculo fibular largo, porque mantiene un nivel mayor de activación muscular, especialmente durante los movimientos dinámicos y la inversión súbita del tobillo, pudiendo beneficiar selectivamente a los individuos con IFT. La VK no presentó efecto superior con relación a la SV, y demostró beneficio mínimo cuando usada para IFT. Además, es probable que su uso cause nueva lesión en el tobillo.

Descriptores: atletas; tobillo; articulación del tobillo; ligamentos articulares.

\section{INTRODUCTION}

Sports participation among university athletes in Malaysia has progressed and outshine. Their level of participation had reached as high as the Olympic. However, in some of the athletes their participation or achievement remains stagnant due to their injuries. Ankle injuries are known to be one of the commonest reported. Yet, there are still lack of local data and research describing the incidence of ankle injuries among the university athletes in Malaysia.

In reference to the US data, it has been estimated that ankle injury occurs almost every day per 10,000 of the population, accounting about 1 million people visited a physician for an acute ankle injury each year. Many people sustained traumatic injury of the ankle, resulted from sports activities. Ankle sprains contribute approximately 19-23\%from all sports injuries.At worst, some studies had suggested that $40 \%$ of ankle sprains are mismanaged and poorly treated, leads to chronic ankle pain and disability. Meanwhile, if we look at the ankle reinjured rate, it is known to be quite high, roughly about $73 \%$. ${ }^{1,2,3}$

In many previous studies, they had suggested few measures and techniques in preventing ankle injury includes specific strength training of the peroneus longus muscles, proprioceptive training and usage of external support, such as braces and taping., ${ }^{4,5}$, However, despite of the suggested preventive measures given, ankle injuries and reinjured data are still high, therefore it is very essential to identify any new or additional specific injury prevention strategies that we can applying order to improve this ankle injury incidence.

In untreated or mismanaged ankle injuries, complications such as chronic pain, chronic ankle joint instability, early-onset arthritis in that joint may develop. The chronic ankle instability is caused by repetitive bouts of ankle instability, resulting in multiple episodes of ankle sprains which may lead to residual symptoms, including recurrent injury ${ }^{7,8}$. There are two proposed causative elements for this chronic ankle instability which are mechanical instability and functional instability ${ }^{9,10}$.

In functional instability of the ankle there is chronic ankle instability with neuromuscular and proprioceptive deficits involvement; thus patients usually experienced symptom of giving way. Meanwhile, in mechanical instability of the ankle there is structural damage to the ligaments following an injury causing the ankle movement had to go beyond its physiological limit of the ankle's range of motion.
The increase in this joint range had diminished the ability of the joint to passively restrain excessive movement, causing give way under mild stress. However, the mechanical instability alone cannot attribute to chronic instability, therefore some individuals with chronic instability do not have joint laxity ${ }^{7,8}$. The combination of the mechanical instability, impaired proprioception and weak musculature, may cause the functional instability of the ankle joint to develop $8,11,12$.

Individuals with ankle instability have experience issues with stability mainly the frontal plane stability; they have poorer stability than those with no ankle injury. The time delay from initiation of the ankle inversion movement to onset of the response of peroneus longus and brevis is known as the peroneal latency or closed loop reflex response ${ }^{12,13,14}$. The timely activation of these muscles after the ankle is forced into inversion is critical to maximizing ankle stability 9 . A delay in the activation of the peroneus longus and peroneus brevis muscles is thought to contribute to the risk of inversion ankle sprain. Therefore, as the peroneus longus muscle acts as the primary everters and dynamic stabilizers of the ankle, its function in relation to ankle stability and lateral sprains has been extensively studied. Interestingly, many of the studies had shown conflicting results with respect to the latency period of the muscle action; the possibility of a longer latency of the peroneus longus muscles in individuals with unstable ankles was inconsistent ${ }^{13,15}$. There is, however, evidence to suggest that dynamic peroneus activity may be impaired in those with functional ankle instability and should be restored in 8 maximize the ankle stabilization 1,7,10.

In a few new researches, authors suggested that ankle taping or bracing was beneficial as it provides mechanical stability and also reduces peroneal latency period. The mechanism responsible for these is the improvement of the postural control after the application of tape or bracing which may stimulate the cutaneous exteroreceptores from the foot and ankle ${ }^{16,17}$. It was also proposed that greater preactivation of the peroneus muscles prior to inversion stress may overcome the electromechanical delay (from activation to force production of the muscle), which could result in a larger spindle response $e^{9,18}$. The peroneus muscle activation is also essential to counteract potentially injurious forces upon landing. It has been proposed that taping can decrease peroneal latency time through providing cutaneous cues ${ }^{19,20}$. It was found to be decreased during sudden weight-bearing inversion in subjects with mechanically unstable ankle $\mathrm{e}^{21,22}$. 
There are two proposed mechanisms on how ankle taping can decrease both the incidence and recurrent of ankle injuries; the mechanical support and the proprioception theory. Taping, without doubt, add mechanical support to the ligaments and limits the extreme ranges of motion at the talar and subtalar joints. Hence, the range for inversion can be reduced especially under weight-bearing conditions $^{15,23}$. It was known that tape may loosen following exercise; the reduction in movement restriction is not enough to diminish its ability to prevent ankle sprains. Hence, the alternative theory of initial and residual restriction provided by taping may prevent ankle sprains has been proposed. Total inversion, average inversion velocity and maximum inversion velocity can be reduced with taping. The inversion velocity is reduced and maximum inversion time is increased, may provide time for the body's natural reflexes to be activated, and thus prevent inversion or decrease the severity of the injurious moment. Meanwhile in the propioception theory, the impaired proprioception in the form of inadequate foot position awareness may result in poor foot placement and consequently re-injury. Taping has the benefit in view of the traction applied on the skin which may increase cutaneous input in the afferent nerves, provide cutaneous cues of foot position and orientation to promote appropriate foot placement and therefore prevent re-injury ${ }^{15,21-23}$.

\section{OBJECTIVE}

The main purpose of the study is to determine the peroneus longus muscle activity as a primary everter and dynamic stabilizer of the ankle in the different taped ankles among functional ankle instability subjects. It is hypothesized that, as an overall view, due to the cutaneous input from different tape conditions, mean peak muscle activation levels would be greater and peroneal latency would be reduced than those seen in the non-taped condition

The secondary purpose of this study is to evaluate the activity of peroneus longus muscle in different ankle positions; in this study we do the test during single leg standing (isometric contraction), vertical jumping (dynamic) and sudden ankle inversion.

The outcome from this study is beneficial to the sports medicine practitioners in their management of ankle injury and the restoration of full function for athlete performance. This study will also help the athletes, trainers and coaching staffs in selecting the most effective method in improving activation of particular muscle in relation to stability and hence prevent injury, recurrences and disability. The findings can further suggest the selection for appropriate type of tape usage in enhancing muscle activation for injury prevention purposes.

\section{MATERIALS AND METHODS}

Materials and methods of this study was obtained and approved by Medical Ethics Commitee, University Malaya Medical Centre by protocol number 974.20. Each participant of this study was voluntarily involved and informed consent form was signed and obtained prior to the tests.

23 participants (18 male and 5 female) with ankle instability volunteered for this study (mean age \pm SD, $21.0 \pm 3.3 \mathrm{yrs}$ ). Ankle instability was defined as a score of $\geq 26$ out of 48 on the Ankle Joint Functional Assessment Tool (AJFAT). The average $( \pm S D)$ CAIT score of the ankles tested was $18( \pm 5)$. Participants had a history of on average, 6 sprains on their test leg with an average of $6( \pm 8)$ months since their last sprain. Exclusion criteria werehistory of fracture of the lower limb, history of surgery done to the lower limb, an ankle sprain within the last three weeks, tenderness or effusion of the ankle at the time of testing, neurological, visual or vestibular deficit or other orthopedic or arthritic problem in the test leg which may affect performance, or any other significant injury or condition likely to cause a disturbance of balance or affect the participant's performance. They were informed that the aim of the study was to compare two type of tape used in ankle taping, referred to as "rigid" (non-elastic tape) and "kinesio" (elastic tape) taping. Participants were debriefed at the conclusion of testing regarding the true purpose of the study.

Participants were tested under three conditions in random order: 1) no tape, 2) kinesio tape, and 3) rigid tape. For each condition, in a random orderparticipants completed two postural stability tests, the single-limb stand test and the single-limb jump test followed by sudden inversion perturbation test. Duration is approximately 20 seconds for each test with 5 minutes interval. Taping method and tests were conducted by the same researcher. For each subject, the tests were one-off and conducted on the same day for every test

Prior to data collection participants were given instructions and the examiner demonstrated each test. Participants then completed three practice trials of each test without the ankle taped. During data collection participants completed three trials of each test under each condition. The best effort was used for data analysis.

Ankle Joint Functional Assessment Tool (AJFAT) is an excellent assessment tool which can discriminate between stable and unstable ankle ${ }^{24}$. The tool had 12 questions that rated (1) ankle pain, (2) ankle swelling, (3) ability to walk on uneven surfaces, (4) overall feeling of stability, (5) overall ankle strength, (6) ability to descend stairs, (7) ability to jog, (8) ability to change direction when running, (9) overall activity level, (10) ability to sense a "rollover" event, (11) ability to respond to a "rollover" event, and (12) ability to return to activity after a "rollover" event.Subjects will choose the answers that best described the ankle using the following scale: much less than the other ankle, slightly less than the other ankle, equal in amount to the other ankle, slightly more than the other ankle, or much more than the other ankle. Each answer has a value between 0 and 4. Higher point values represent greater functional limitations. All scores will be added to give a total score on the AJFAT. The maximum possible score is $48^{24,25}$.

The rigid tape consisted of a technique commonly used by sports physiotherapists and athletes to prevent ankle inversion injuries. An anchor, three stirrups, a low anchor, a basket weave and, a heel lock were applied using unelastic tape. An underwrap was used prior to tape application ${ }^{16-18}$.

For kinesiotaping applications, Kenzo Kase's KinesioTM taping manual (Kase et al., 1996)26 were applied. Each subject's foot was placed in relaxed position while they sat on a taping table with the ankle in slight plantar flexion. The first strip of tape was placed from the anterior midfootand attached just below the anterior tibial tuberosity over the tibialis anterior muscle. The second strip began just above the medial malleolus and wrap around the heel like a stirrup, attaching just lateral to the first strip of tape. The third strip stretched across the anterior ankle, covering both the medial and lateral malleolus. Finally, the fourth strip originated at the arch and stretched slightly, measuring 4-6 inches above both the medial and lateral malleolus consisted of a single strip of inelastic tape approximately $10 \mathrm{~cm}$ long on the lateral aspect of the lower leg above the lateral malleolus. The tape was aligned vertically over the tendon of peroneus longus ${ }^{14,16,17}$.

\section{Static stability test and EMG recording}

Surface EMG from Motion Lab Systems Inc was used; electrode placement was performed prior to static stability test. 2 MA-411 EMG preamplifier electrodes was placed on the peroneus longus muscle belly at the upper lateral leg. Base-line activity during the 200 milliseconds prior to the static stability test was sampled at $1600 \mathrm{~Hz}$ with a signal bandwidth of 10 to $500 \mathrm{~Hz}$. Subject will then be preceded to the stability test ${ }^{6,7,20}$. 
Static stability was performed when the stance leg was flexed slightly at the knee, the non-weight-bearing leg was in $45^{\circ}$ of knee flexion, and the hip may be slightly flexed up to $20^{\circ}$ to $30^{\circ} 27$. The hands were placed on the hips. EMG data was sampled during along this test

\section{Dynamic stability test and EMG recording}

As in static stability test, EMG activity data is recorded 200 milliseconds prior to dynamic stability test at $1600 \mathrm{~Hz}$ with signal bandwidth of 10 to $500 \mathrm{~Hz}$ as well and recorded along the test.

Participant's maximum 2-footed vertical jump height was measured. They jumped from $70 \mathrm{~cm}$ away from a Vertec. Participant must use a jumping technique but they were permitted to swing their arms then required holding their reaching arm at $180^{\circ}$ of shoulder flexion. Adjustable plastic rods on the Vertec allowed jump height assessment. Then the plastic rods on the Vertec were set at $50 \%$ of a subject's maximal jump.

While standing $70 \mathrm{~cm}$ away, participantused a 2-footed jump to reach the $50 \%$ mark with their fingertips. Participant could swing their arms during this jump, but they were required to hold the reaching arm at $180^{\circ}$ of shoulder flexion after takeoff. The reaching arm must be ipsilateral to the ankle been tested. Participant must "stick" the landing on the force platform on their test leg, stabilize as quickly as possible, and remain as motionless as possible in a single leg stance for 20 seconds ${ }^{27-29}$.

\section{Sudden inversion perturbation testand EMG recording}

During this test, the participant stood on 1 foot on a balance board as a $10 \mathrm{~kg}$ weight was dropped down a slot onto the backside of the lateral side of the board, without warning, creating an inversion perturbation of 150. The balance board was aligned with the slots down which the weight consistently landed in the same place. The slot also served the purpose of guiding the weight to the side (away from the test area) after it landed. The slots were wide enough for the weight to pass through them without touching, so as to avoid sounds made by friction. Three trials, with a 40-second rest between each, were collected for each condition. At the end of each session, the participant was asked to determine which of the 3 conditions he perceived as being the most stable and the least stable?

Variables of interest included the mean and peak magnitude of the EMG signal and the time from inversion to peak EMG. The time to peak and duration of the response is task dependent. As well as the magnitude of the response to inversion, allowing for latency, peak, and duration of the response to be measured.

\section{Statistical analysis}

Data were analyzed with SPSS, Version 19.0. The analysis of variance (Independent T-test and ANOVA) was used to evaluate differences in muscle activity. For EMG activity, the raw EMG data were high-pass filtered at $30 \mathrm{~Hz}$, full wave rectified, and the root-mean-square of the signal was derived using a moving window of 100 milliseconds. All data were normalized to the maximum signal collected.

\section{RESULTS}

For peak muscle activation, this study showed that peroneus muscles were activated more in RT group compared to NT and KT during the Static Stability Test (Figure 1 and Table 1). Otherwise it showed no statistically significant differences within the group during this particular test (NT/RT p=0.590, NT/KT p=0.895, RT/KT p=0.435, NT/RT/KT p=0.761). Similar finding noted during the Dynamic Stability Test (Figure 1 and Table 2), peroneus muscle in RT group were more activated compared with 2 other groups but statistically showed no significant differences (NT/RT $p=0.114, N T / K T p=0.970, R T / K T p=0.166$ NT/RT/KT $p=0.232$ ).
Meanwhile during sudden inversion perturbation test (Figure 1and Table 3), RT group activated peroneus longus muscle more than the other groups, interestingly, there were significant differences $(p=0.001)$ between RT group compared with NT group and RT group compared with NT and KT ( $p=0.001)$. However no significant difference between NT and KT group and RT and KT group ( $p=0.750$ and $p=0.006$ ).

While for peroneal latency, our study showed different results. During the Static Stability Test (Figure 2 and Table 1), peroneal latency were even delayed in KT and RT group compared to NT with no statistically significant differences as well (NT/RT $p=0.192$, NT/KT $p=0.223, R T / K T p=0.973, N T / R T / K T p=0.369$ ). Almost similar finding in Dynamic Stability Test (Figure 2 and Table 2) and Sudden Inversion Perturbation Test (Figure 2 and Table 3). Peroneal latency were shorter in NT group compared with RT and KT group. This peroneal latency differences between groups were proven statistically when there were significant differences between NT and KT group $(p=0.001)$ and between NT, RT and KT group ( $p=0.001$ ) during Dynamic Stability Test while no significant differences between other groups both in Dynamic Stability Test (NT/RT $p=0.280$, RT/KT $p=0.010$ ) and Sudden Inversion Perturbation Test (NT/RT $p=0.646$, NT/KT $p=0.423, \mathrm{RT} / \mathrm{KT}$ $p=0.564, N T / R T / K T p=0.460$ ).

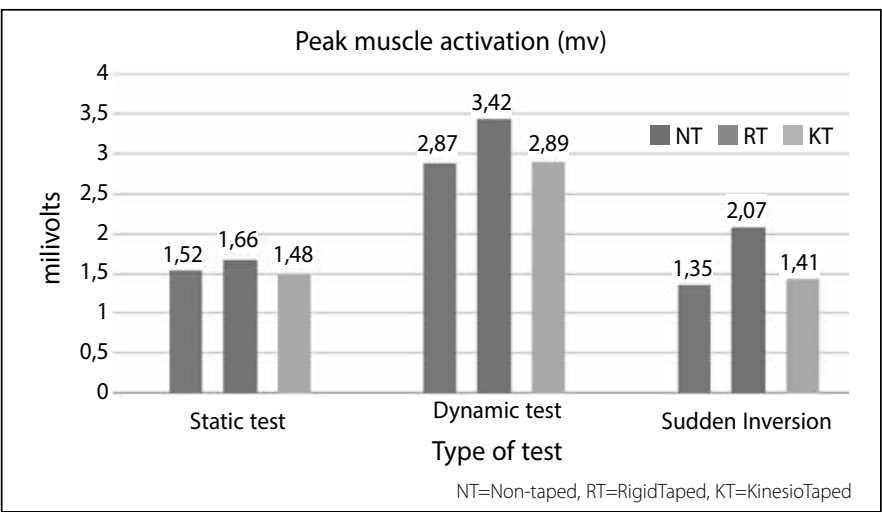

Figure 1. Peak Muscle Activation (mV) of Each Test and Type of Taping.

Table 1. Static Stability Test Resultswith peak activation \& peroneal latency.

\begin{tabular}{|c|c|c|c|c|c|c|c|c|}
\hline & \multicolumn{4}{|c|}{ Peak Activation } & \multicolumn{4}{|c|}{ Peroneal Latency } \\
\hline & $\begin{array}{c}\text { Mean } \\
(\mathrm{mV})\end{array}$ & SD & $\begin{array}{c}\text { Sig } \\
\text { (2-tailed) }\end{array}$ & $\begin{array}{c}\text { Confiden- } \\
\text { ce } \\
\text { interval }\end{array}$ & $\begin{array}{c}\text { Mean } \\
(\mathrm{mV})\end{array}$ & SD & $\begin{array}{c}\text { Sig } \\
\text { (2-tailed) }\end{array}$ & $\begin{array}{c}\text { Confiden- } \\
\text { ce } \\
\text { interval }\end{array}$ \\
\hline \multirow[t]{2}{*}{ NT/RT } & 1.52 & 1.072 & 0.590 & 95 & 129.13 & 40.61 & 0.192 & 95 \\
\hline & 1.66 & 0.751 & & & 146.87 & 49.73 & & \\
\hline \multirow[t]{2}{*}{$\mathrm{NT} / \mathrm{KT}$} & 1.52 & 1.071 & 0.895 & 95 & 129.13 & 40.61 & 0.223 & 95 \\
\hline & 1.48 & 0.849 & & & 146.35 & 53.12 & & \\
\hline \multirow[t]{2}{*}{$\mathrm{RT} / \mathrm{KT}$} & 1.66 & 0.751 & 0.435 & 95 & 146.87 & 49.73 & 0.973 & 95 \\
\hline & 1.48 & 0.849 & & & 146.35 & 53.12 & & \\
\hline
\end{tabular}

Table 2. Synamic Stability Test Results with peak activation \& peroneal latency.

\begin{tabular}{|c|c|c|c|c|c|c|c|c|}
\hline & \multicolumn{4}{|c|}{ Peak Activation } & \multicolumn{4}{|c|}{ Peroneal Latency } \\
\hline & $\begin{array}{c}\text { Mean } \\
(\mathrm{mV})\end{array}$ & SD & $\begin{array}{c}\text { Sig } \\
\text { (2-tai- } \\
\text { led) }\end{array}$ & \begin{tabular}{|c|} 
Confi- \\
dence \\
interval
\end{tabular} & $\begin{array}{c}\text { Mean } \\
(\mathrm{mV})\end{array}$ & SD & $\begin{array}{l}\text { Sig } \\
\text { (2-tai- } \\
\text { led) }\end{array}$ & $\begin{array}{l}\text { Confiden- } \\
\text { ce } \\
\text { interval }\end{array}$ \\
\hline \multirow[t]{2}{*}{ NT/RT } & 2.87 & 1.094 & 0.114 & 95 & 125.48 & 63.32 & 0.280 & 95 \\
\hline & 3.42 & 1.204 & & & 144.96 & 57.28 & & \\
\hline \multirow[t]{2}{*}{$\mathrm{NT} / \mathrm{KT}$} & 2.87 & 1.094 & 0.970 & 95 & 125.48 & 63.32 & $0.001^{*}$ & 95 \\
\hline & 2.89 & 1.359 & & & 202.30 & 85.21 & & \\
\hline \multirow[t]{2}{*}{ RT/KT } & 3.42 & 1.204 & 0.166 & 95 & 144.96 & 57.27 & $0.010^{*}$ & 95 \\
\hline & 2.89 & 1.359 & & & 202.96 & 85.21 & & \\
\hline
\end{tabular}


Table 3. Sudden Inversio n Test Results with peak activation \& peroneal latency.

\begin{tabular}{|c|c|c|c|c|c|c|c|c|}
\hline & \multicolumn{4}{|c|}{ Peak Activation } & \multicolumn{4}{|c|}{ Peroneal Latency } \\
\hline & $\begin{array}{c}\text { Mean } \\
(\mathrm{mV})\end{array}$ & SD & $\begin{array}{l}\text { Sig } \\
\text { (2-tai- } \\
\text { led) }\end{array}$ & \begin{tabular}{|c|} 
Confi- \\
dence \\
interval
\end{tabular} & $\begin{array}{c}\text { Mean } \\
(\mathrm{mV})\end{array}$ & SD & $\begin{array}{l}\text { Sig } \\
(2-\text { tai- } \\
\text { led) }\end{array}$ & $\begin{array}{c}\text { Confiden- } \\
\text { ce } \\
\text { interval }\end{array}$ \\
\hline \multirow[t]{2}{*}{ NT/RT } & 1.36 & 0.307 & $0.001^{*}$ & 95 & 116.87 & 34.16 & 0.646 & 95 \\
\hline & 2.07 & 0.837 & & & 120.70 & 20.11 & & \\
\hline \multirow[t]{2}{*}{$\mathrm{NT} / \mathrm{KT}$} & 1.35 & 0.307 & 0.750 & 95 & 116.87 & 34.16 & 0.423 & 95 \\
\hline & 1.41 & 0.731 & & & 127.83 & 55.34 & & \\
\hline \multirow[t]{2}{*}{$\mathrm{RT} / \mathrm{KT}$} & 2.08 & 0.837 & 0.006 & 95 & 120.70 & 20.11 & 0.564 & 95 \\
\hline & 1.41 & 0.730 & & & 127.83 & 55.35 & & \\
\hline
\end{tabular}

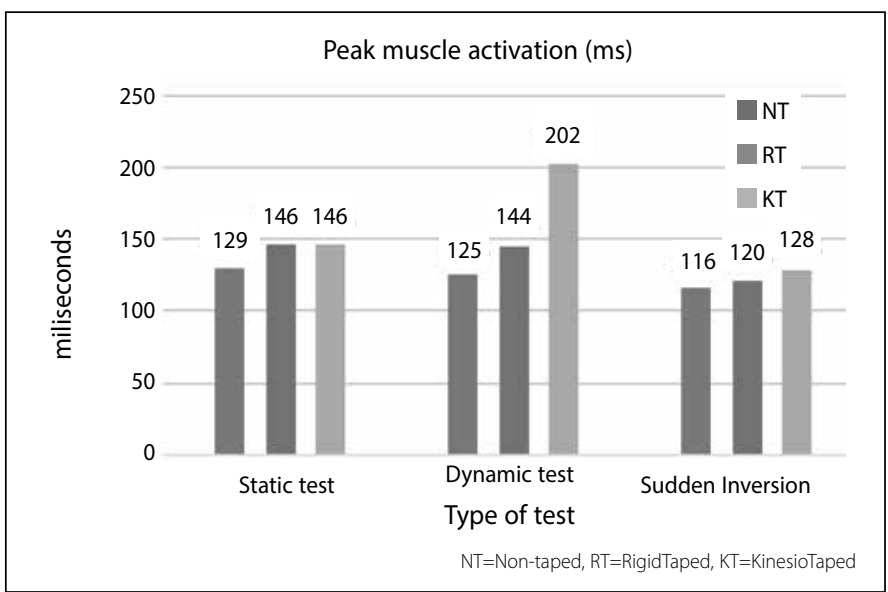

Figure 2. Peroneal Latency (ms) of Each Test and Type of Taping.

\section{DISCUSSION}

The main purpose of this study is to determine the peroneus longus muscle activity in different type of taped ankles among FAl subjects. It was hypothesized that the peak muscle activation levels will be increased than those seen in the non taped condition.

As per hypothesized, peroneus muscles activation were greatest in RT group in all three different tests with statistically significant $(p=0.001)$ between NT and RT group and NT and KT group during sudden inversion perturbation test. This results supported a study by Briem et al. ${ }^{1}$ where they found greatest peroneus activation in RT group during sudden inversion perturbation test. However in RT group during the other 2 tests indicated no significant difference even though peroneus muscle activity were activated more compared to other groups, a greater sample size might have demonstrated significance.

Nevertheless, our hypotheses that the delay of peroneal latency in FAl subjects would have been reduced were not supported by our data. During all the three test, NT group indicated the shortest peroneal latency which means rather RT or KT did not reduce the peroneal latency to provide mechanical stability to the FAl participants. These results are against what had been showed by Karlsson and Andreasson where tape application shortened peroneal latency in unstable ankle. It is more obvious during our Dynamic Stability Test.
Although during Static Stability Test and Sudden Inversion Perturbation Test, results indicated almost equal readings in NT, RT and KT otherwise not statistically significant. This may suggest that ankle taping do not reduce peroneal latency during the dynamic and aggressive movements of the ankle joint.

We acknowledged that in this study, we were only evaluating level of muscle activation on surface EMG and do not represent the muscle output with respect to actual force which can be evaluated through needle EMG which is an invasive procedure.

Rigid tape is known to lose some of its restrictive properties after exercise, and we did not evaluate the effects of either tape after exercise ${ }^{30,31}$. The efficacy of the KT may have been affected by the slit for the electrode. However, many applications of KT involve splitting the tape, with each tail of the strip bordering the index muscle, as in the setup of the present study. Furthermore, previous studies have similarly adapted placement of KT strips for the purpose of investigating the effects of taping on muscle activity and found significant differences in surface EMG recordings.

The movements during the tests, especially Dynamic Stability Test where participants had to perform vertex jumping and landing were largely influenced by other large joints such as vertebra, hip and knee. Therefore, this weight bearing and gravity will influence the maneuver and made it difficult to isolate the peroneus longus muscle activity.

\section{CONCLUSION}

It was well known that ankle taping with RT tape may enhance the peroneus longus muscle response by maintaining greater level of muscle activation especially during the dynamic movements and sudden inversion of the ankle. This may selectively benefit individuals with FAl.

Interestingly, the taped ankle did not show any reduction in the peroneal latency in FAl, in other words do not substantially provide mechanical stability in FAl. However the effects are actually more prolonged mainly in the KT ankle. The KT ankle has more or less similar peroneus muscle activation and peroneal latency reading to the NT ankle, which suggestive that the KT has no superior effect than NT ankle. Furthermore, the dynamic test showed significantly prolonged peroneal latency duration, this highly suggestive that the KT has least benefit if used in FAl and the usage might have higher chances of causing reinjury to the ankle.

\section{ACKNOWLEDGMENTS}

The help and advice of Associate Professor Dr. Mohd Nahar Azmi, Head of Sports Medicine University of Malaya, Dr.Zulkarnain Jaafar and Dr. Goh Siew Li, Senior Lecturers in Sports Medicine University of Malaya, Mr. Rizal Razman, Senior Lecturer in Sports Biomechanics University of Malaya Sports Centre, Mr. Nazrin, Senior Biomechanist of National Sports Institute of Malaysia, Proffesor Goh CK, Consultant in Neurology University of Malaya Medical Centre, are appreciated.

All authors have declared there is not any potential conflict of interests concerning this article. 


\section{REFERENCES}

1. Briem K, Eythörsdöttir H, Magnúsdóttir RG, Pálmarsson R, Rúnarsdöttir T, Sveinsson T. Effects of kinesio tape compared with nonelastic sports tape and the untaped ankle during a sudden inversion perturbation in male athletes. J Orthop Sports PhysTher. 2011;41(5):328-35.

2. Boyce SH, Quigley MA, Campbell S. Management of ankle sprains: a randomised controlled trial of the treatment of inversion injuries using an elastic support bandage or an Aircast ankle brace. $\mathrm{Br} J$ Sports Med. 2005;39(2):91-6.

3. Kerkhoffs GM, van den Bekerom M, Elders LA, van Beek PA, Hullegie WA, Bloemers GM, et al. Diagnosis, treatment and prevention of ankle sprains: an evidence-based clinical guideline. Br J Sports Med. 2012;46(12):854-60

4. Garrick JG, Requa RK. Role of external support in the prevention of ankle sprains. Med Sci Sports. 1973;5(3):200-3.

5. Garrick JG, Requa RK. The epidemiology of foot and ankle injuries in sports. ClinPodiatr Med Surg. 1989;6(3):629-37.

6. Suda EY Pereira CS, Sacco ICN. Vertical ground reaction forces and emg during landing in functionally unstable ankle. In: XXV International Symposium on Biomechanics in Sports, 2007. OuroPreto, Brazil; 2007.

7. Kaminski TW, Hartsell HD. Factors Contributing to Chronic Ankle Instability: A Strength Perspective. J Athl Train. 2002;37(4):394-405.

8. Tropp H. Commentary: Functional Ankle Instability Revisited. J Athl Train. 2002;37(4):512-515.

9. De Luca CJ. Surface electromyography: detection and recording. Strathmore Rd, Natick, Estados Unidos: DelsysIncorporated; 2002. Disponível em: https://www.delsys.com/Attachments_pdf/WP_SEMGintro.pdf

10. Hertel J. Functional Anatomy, Pathomechanics, and Pathophysiology of Lateral Ankle Instability. J Athl Train. 2002;37(4):364-375.

11. Dodd A, Dyson R, Peters R. Moderation of Lower Limb Muscular Activity During Jump Landing by the application of ankle taping. In: Anderson R, Harris D, Kenny I, editors. Proceedings of the XXVII International Conference on Biomechanics in S ports. Chichester, UK: University of Chichester; 2009.

12. Miller EA, Hergenroeder AC. Prophylactic ankle bracing. PediatrClin North Am. 1990;37(5):1175-85.

13. Knight A, Weimar W. Peroneal latency's role in inversion ankle sprain, 2012. Disponivel em: http:// lermagazine.com/article/peroneal-latencys-role-in-inversion-ankle-sprain. [Acessadoem: 201508 jun].

14. Thacker SB, Stroup DF, Branche CM, Gilchrist J, Goodman RA, Weitman EA. The prevention of ankle sprains in sports? a systematic review of the literature. Am J Sports Med. 1999;27(6):753-60

15. Konradsen L, Ravn JB. Prolonged peroneal reaction time in ankle instability. Int J Sports Med. 1991;12(3):290-2.
16. Cerney, J.V. Complete book of athletic taping techniques. New York: Parker; 1972.

17. Capasso G, Maffulli N, Testa V. Ankle taping: support given by different materials. Br J Sports Med. 1989;23(4):239-40.

18. Riemann BL, Schmitz RJ, Gale M, McCaw ST. Effect of ankle taping and bracing on vertical ground reaction forces during drop landings before and after treadmill jogging. J Orthop Sports PhysTher. 2002;32(12):628-35.

19. Kamen G. Electromyographic kinesiology. Robertson DG, Hamill J, Caldwell GE, Kamen G, editors. Research methods in biomechanics. Champaign, IL: Human Kinetics; 2004. p. 163-83.

20. Hertel J. Functional instability following lateral ankle sprain. Sports Med. 2000;29(5):361-71.

21. Wilkerson GB. Biomechanical and Neuromuscular Effects of Ankle Taping and Bracing. J Athl Train. 2002;37(4):436-445

22. Heit E, Lephart S, Rozzi S. The effect of ankle bracing and taping on joint position sense in the stable ankle. J. Sport Rehabil. 1996;5:206-13.

23. Karlsson J, Lansinger O. Lateral instability of the ankle joint. ClinOrthopRelat Res. 1992;(276):253-61.

24. Schulz MR, Marshall SW, Yang J, Mueller FO, Weaver NL, Bowling JM. A prospective cohort study of injury incidence and risk factors in North Carolina high school competitive cheerleaders. Am J Sports Med. 2004;32(2):396-405.

25. Ross SE, Guskiewicz, Gross MT, Yu B. Assessment Tools for Identifying Functional Limitations Associated With Functional Ankle J Athl Train. 2008;43(1):44-50.

26. Kase K. Taping perfect manual: amazing taping therapy to eliminate pain and muscle disorder. Korea: Ken Ikai Co Ltd; 1996.

27. McKeon PO, Hertel J. Spatiotemporal postural control deficits are present in those with chronic ankle instability. BMC MusculoskeletDisord. 2008 9:76.

28. Ross SE, Guskiewicz KM, Gross MT, Yu B. Balance measures for discriminating between functionally unstable and stable ankles. Med Sci Sports Exerc. 2009;41(2):399-407.

29. Sefton JM, Hicks-Little CA, Hubbard TJ, Clemens MG, Yengo CM, Koceja DM, et al. Sensorimotor function as a predictor of chronic ankle instability. ClinBiomech (Bristol, Avon). 2009;24(5):451-8.

30. Lohrer H, Alt W, Gollhofer A. Neuromuscular properties and functional aspects of taped ankles. Am J Sports Med. 1999;27(1):69-75.

31. Purcell SB, Schuckman BE, Docherty CL, Schrader J, Poppy W. Differences in ankle range of motion before and after exercise in 2 tape conditions. Am J Sports Med. 2009;37(2):383-9. 